Summer 2015

\title{
No Simple Fix: Fiscal Rules and the Politics of Austerity
}

\author{
Alasdair Roberts \\ University of Missouri, alasdair.roberts@gmail.com
}

Follow this and additional works at: https://www.repository.law.indiana.edu/ijgls

Part of the International Law Commons, and the Legislation Commons

\section{Recommended Citation}

Roberts, Alasdair (2015) "No Simple Fix: Fiscal Rules and the Politics of Austerity," Indiana Journal of Global Legal Studies: Vol. 22 : Iss. 2 , Article 6.

Available at: https://www.repository.law.indiana.edu/ijgls/vol22/iss2/6

This Symposium is brought to you for free and open access by the Law School Journals at Digital Repository @ Maurer Law. It has been accepted for inclusion in Indiana Journal of Global Legal Studies by an authorized editor of Digital Repository @ Maurer Law. For more information, please contact rvaughan@indiana.edu.

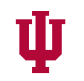

JEROME HALL LAW LIBRARY

$$
\text { INDIANA UNIVERSITY }
$$

Maurer School of Law
Blooming ton 


\title{
No Simple Fix: Fiscal Rules and the Politics of Austerity
}

\author{
ALASDAIR ROBERTS*
}

ABSTRACT

Fiscal rules were supposed to provide a simple remedy for out-ofcontrol government spending. They were predicated on a deep skepticism about the capacity of democratic systems to exercise fiscal self-control. After three decades of experimentation, it is evident that advocates of fiscal rules overestimated the capacity of legal instruments to impose discipline on democratic processes. Certainly, many advanced democracies have improved their fiscal performance-but fiscal rules have played a small role in this process. Experience suggests that advocates of fiscal rules drew the wrong lessons from the experience of the 1970s, and underestimated the capacity of democratic systems to respond constructively to fiscal crises.

"[A] historical phenomenon can never be understood apart from its moment in time."

- Marc Bloch 1

\section{INTRODUCTION}

A fiscal rule is a legal instrument that intends to limit what democratically elected governments can do in terms of spending, taxing, and borrowing. ${ }^{2}$ In this paper we are only interested in fiscal rules affecting national governments. Such rules vary in form. They may be

* Alasdair Roberts is a Professor of Public Affairs at the Truman School of Public Affairs, University of Missouri. He is a Fellow of the National Academy of Public Administration and a public member of the Administrative Conference of the United States. His website is http://www.aroberts.us.

1. Marc Bloch, The Historian's Craft 35 (Alfred A. Knopf ed., Peter Putnam trans., 1953).

2. See generally George Kopits \& Steven Symansky, Fiscal Policy Rules 2-4 (Int'l Monetary Fund ed., 1998) (assumes that fiscal rules permanently constrain fiscal policy in terms of overall fiscal performance).

Indiana Journal of Global Legal Studies Vol. 22 \#2 (Summer 2015)

(C) Indiana University Maurer School of Law 
contained in treaties-like the Treaty on European Union of 1992 and the Treaty on Stability, Coordination and Governance of 2012-which attempt to limit borrowing by countries that use the euro as their currency. ${ }^{3}$ Or they may be contained in national constitutions, like the provision in Singapore's basic law that promotes budget balance over the five-year term of a government. ${ }^{4}$ Or they may be contained in legislation-like the Budget Control Act of 2011, which was intended to force reductions in spending by the United States Congress over the following decade. ${ }^{5}$ Or they may be contained in high-profile statements, like the three-year commitments on expenditure levels that the Swedish government began to publish in $1997 .{ }^{6}$ As these examples suggest, fiscal rules also vary in purpose. They may limit expenditures, deficits, or total debt, and they may measure these variables in terms of national currency or as a share of GDP. ${ }^{7}$

This meaning of the phrase "fiscal rule" was unknown before the neoliberal age-that is, the period that began with the pro-market policies of Ronald Reagan and Margaret Thatcher. There were certainly experiments with legal constraints on national fiscal policy in some places before 1980, as well as scholarly work that laid out the argument for such constraints; however, the idea that national governments should be bound by fiscal rules only became fashionable in many countries after 1980 , and particularly after the early $1990 \mathrm{~s} .{ }^{8}$ These rules were seen as a remedy for a grave defect in the structure of advanced democracies, which were believed to have a tendency toward increasing expenditures and indebtedness. ${ }^{9}$ Democracies that were otherwise incapable of controlling themselves would be constrained by constitutions, statutes, or treaties. Advocates of fiscal rules combined skepticism about the self-denying capacities of democratic systems with

3. See TEU art. 104 (as in effect 1993) (now TFEU art. 126); Treaty of Lisbon Amending the Treaty on European Union and the Treaty Establishing the European Community, protocol 12, Dec. 13, 2007, 2007 O.J. (C 306) 1 [hereinafter Treaty of Lisbon]; Treaty on Stability, Coordination and Governance in the Economic and Monetary Union, art. 3, Mar. 2, 2012 [hereinafter TSCG].

4. See Const. of the RePublic of Singapore Aug. 9, 1965, Part XI (142).

5. See generally Budget Control Act of 2011, Pub. L. No. 112-25, 125 Stat. 240 (2011) (outlining several measures aimed at deficit reduction).

6. See Gösta Ljungman, The Medium-Term Fiscal Framework in Sweden, 6 OECD J. ON BUDGETING 1, 4 (2007).

7. See Andrea Schaechter et al., Fiscal Rules in Response to the Crisis-Toward the 'Next Generation' Rules. A New Dataset, 7-10 (IMF Working Paper No. 12/187, 2012).

8. Alex alasdair, The logic of Discipline: Global Capitalism and the NeW ARCHITECTURE OF GOVERNMENT 57-64 (2010).

9. Id. at $48-49$. 
a deep faith in the power of the law to regulate the politics of taxing and spending. 10

The era of unabashed neoliberalism ended with the advent of the global financial crisis in 2008. By then, the world had three decades of discouraging experience with national fiscal rules. The results were not encouraging for advocates of fiscal constraints. Many governments had carefully avoided fiscal rules that would constrict their discretion over spending, taxing, and borrowing. Some governments learned how to evade their own rules, or decided to modify or abandon them when they became inconvenient. Other governments that were already pursuing austerity policies adopted fiscal rules for purely symbolic reasons. The results of these three decades were not entirely disappointing: many governments had improved their budgetary behavior, but there was no clear evidence that fiscal rules had caused them to do it.

The doctrine that surrounded fiscal rules proved to be misguided in two respects. The first error, clearly, was its assumption that the discretion of national governments could be effectively contained through legal instruments. The second, more fundamental, error was that proponents of fiscal rules looked at the behavior of advanced democracies at a specific moment in history, and derived a highly abstracted and pessimistic view about the character of democratic politics. A more accurate reading of history accounts for the particular conditions that encouraged a loss of fiscal discipline in the 1970 s and early 1980s. It also recognizes how the advanced democracies adapted to manage that problem, through a long process of ideational as well as institutional change.

Fiscal rules are included within a set of institutional innovations that were widely adopted in the neoliberal age and which are frequently regarded as constraints on democratic politics. ${ }^{11}$ This paper suggests a more encouraging view of recent history: fiscal rules were not imposed as constraints on democratic politics; rather, they were used (and often abused) by democratic polities in a complicated process of adjustment to new economic and social realities. Democratic states have not surrendered their capability to abandon or evade such rules when it seems to be in the national interest. In the long run, enthusiasm for fiscal rules may fade. We may begin to recognize this wave of experimentation with fiscal rules as a distinct historical phenomenon, a

10. Id. at $57-64$.

11. Central bank independence is another example of reforms within this set. See generally Alasdair RoBERTs, THE LOGIC OF DISCIPLINE: GLOBAL CAPITALISM AND THE ARCHITECTURE OF GOVERNMENT (2010) (arguing that governmental reform, occurring from 1978 to 1980 , resulted in economic liberalization and a simultaneous constraint on the role of government). 
small part of a much larger story about democratic adaptation to the realities of fiscal stress.

\section{The Rise Of The Simple Fix: Public Choice}

Before the 1980s, a "fiscal rule" was usually understood to mean a rule of thumb or guideline that might be applied to governmental taxing and spending, particularly in the context of the attempt to steer the overall performance of a national economy. Most experts did not seriously contemplate the possibility that governments might adopt legal constraints on fiscal policy. The shift in understandings about the meaning of the phrase, and about the wisdom of legal constraints, was the result of three intellectual and political projects: one American, one primarily German, and one closely associated with supranational institutions such as the European Commission and the International Monetary Fund (IMF). All three of these projects shared a common skepticism about the trustworthiness of democratic processes, and they shared a faith in the power of the law to regulate politics.

The intellectual leaders of the American project were a small group of academics, initially based at the University of Virginia, whose aim was to apply economic modes of analysis to political and bureaucratic decision making. Two leaders of this group were James Buchanan and Gordon Tullock, who arrived at the University of Virginia in 1956-1957. The school of thought that they helped to establish eventually became known as Public Choice. It was built on two assumptions. The first assumption was that individuals and groups within government acted just as they did in the marketplace with a keen interest in advancing their own material interests. "The basic behavioral postulate," said Dennis C. Mueller, "is that man is an egoistic, rational, utility maximizer."12 The second assumption was that the behavior of individuals and groups is shaped principally by formal rules that define what they can or cannot do as they pursue their interests. Buchanan was heavily influenced by the Swedish economist Knut Wicksell, who also worked on the axiom that "legal structures" were the only effective way of guiding individual behavior. ${ }^{13}$ Tullock, trained as a lawyer, was also sympathetic to this view. ${ }^{14}$ The effect of combining these two assumptions was to produce a view of government as a simple, formal

12. DenNis Mueller, PUblic Choice III, at 1-2 (3rd ed. 2003).

13. KNUT WICKSELL \& LIONEL ROBBINS, LECTURES ON POLITICAL ECONOMY 5 (Routledge \& Kegan Paul Ltd. ed., E. Classen trans., 1934).

14. Gordon L. Brady \& Robert D. Tollison, Gordon Tullock: Creative Maverick of Public Choice, 71 PUB. CHOICE 141, 142 (1991). 
game, with very little that is high-minded about it. "Policy outcomes," a student of Buchanan's later wrote,

are treated as being a more or less "natural" product of people pursuing their interests through political processes, as this pursuit is shaped and constrained by constitutional rules. Undesirable or inefficient outcomes, then, call for constitutional remedy and not for exhortation to do better, to elect more qualified officials, to be less human, or to follow other similar nostrums. ${ }^{15}$

Public Choice scholars quickly formed the opinion that the game of democratic politics tended to encourage the overproduction of public services. Politicians had an incentive to make large promises to win the next election. Bureaucrats in public agencies had an incentive to promote new programs so that they could increase their budgets and perquisites. Special interest groups had an incentive to lobby for privileges whose costs could be loaded onto the shoulders of lessorganized taxpayers. And voters, in general, had an incentive to press politicians for benefits whose costs could be transferred, by borrowing, to future generations. In sum, the governmental machine was built in such a way that steady expansion was inevitable. Growth was the result of politicians, bureaucrats, and voters engaging in their "natural proclivities" within the rules of the democratic game. ${ }^{16}$ This defect of the democratic process was "inherent and universal." 17

It is probably not surprising that Buchanan himself developed an early and intense antipathy toward the Keynesian approach on macroeconomic management, a theory that became influential after the Second World War. Keynesian economists condoned borrowing by governments to finance new programs during periods of economic decline. The premise was that governments would repay these debts when the economy recovered. But Buchanan was skeptical: he believed that Keynesians, by dispelling the stigma that traditionally surrounded debt-financed expenditure, had created a new "bias toward extended public expenditure."18 Politicians would borrow too much during

15. Richard E. Wagner, The Calculus of Consent: A Wicksellian Retrospective, 56 PUB. CHOICE 153, 153 (1988).

16. James M. Buchanan, The Balanced Budget Amendment: Clarifying the Arguments, 90 PUB. CHOICE 117, 120 (1997) [hereinafter Buchanan, Balanced Budget].

17. William C. Mitchell, Virginia, Rochester and Bloomington: Twenty-Five Years of Public Choice and Political Science, 56 PUB. CHOICE 101, 107 (1988).

18. James M. Buchanan, The Collected Works of James M. Buchanan, Vol. 2 Public Principles of Public Debt: A Defense and Restatement, 95 (1999). 
economic hardship, and fail to repay debt in times of economic prosperity.

There is a contradiction in Buchanan's assault on the Keynesian paradigm, which is never properly acknowledged in his work. The Public Choice perspective emphasizes the natural behavior of selfinterested people within a system of formal rules, but Buchanan's attack on Keynes is primarily a complaint about a shift in ideas. Buchanan acknowledges that government deficits were not a serious problem for the first 150 years of U.S. history, because politicians and voters respected the "norm of budget balance." This was "a widely shared principle," "a moral constraint," 19 and "part of an accepted set of attitudes about how government should, and must, carry on its fiscal affairs." ${ }^{20}$ Buchanan's lament about Keynesianism is that it caused a "shift in ideas on public debt . . . [t] here was no longer any reason for opposing deficit financing on basically moral grounds."21 Two questions are raised. First, how can it be reasonable to say that the U.S. government has a "quite natural tendency to generate budget deficits almost continually" when it is also observed that for the bulk of its history, the U.S. government did not do this?22 Second, how can we regard the behavior of individuals as naturally self-interested, when at the same time we concede that such behavior has been shaped for long periods by norms or "accepted attitudes"?

These are questions to which we shall return later on. For the moment it is sufficient to observe that Buchanan himself did not explore them. His own remedy for the problem of debt-financed expenditure in the post-war period was a change to the formal rules of the game: an amendment to the United States Constitution that would require the federal government to balance its budget. The notion of a constitutional limitation on government borrowing was not new in the United States context: many U.S. state governments operated under such constraints. Several adopted constitutional limitations on borrowing after a string of state defaults on debt during the depression of the early $1840 \mathrm{~s}^{23}$ No similar constraint had ever been imposed on the U.S. federal government. But Buchanan, reverting to his longstanding emphasis on formalities, regarded it as essential. "The structural flaw in our fiscal

19. James M. Buchanan \& Richard E. WAGner, Democracy in Deficit: The PolitiCAL LEGACY OF LoRD KeYNES 10 (Academic Press, Inc. ed., 1977).

20. Buchanan, Balanced Budget, supra note 16, at 119.

21. BUCHANAN \& WAGNER, supra, note 19 , at 16.

22. Geoffrey Brennan and James M. Buchanan, The Power to TaX: ANalytical Foundations OF A FisCal CONSTITUTION 203 (digital paperback ed. 2006) (emphasis added).

23. See, e.g., Alasdair RoBerts, AMERICA'S First GREat DEPRESSION: ECONOMIC CRISIS AND POLITICAL DISORDER AFTER THE PANIC OF 1837, at 49-83 (2012). 
politics . . requires structural correction, that is, constitutional constraint that will, effectively, change the basic rules for the fiscal game."24

By the late 1970s, there was a broad popular movement for the addition of a balanced-budget rule to the United States Constitution, triggered by public dissatisfaction with economic malaise and a succession of federal budget deficits after 1969. In 1975, the Maryland and Mississippi legislatures petitioned Congress to establish a convention to draft a balanced-budget amendment. By 1979, twentyfour other state legislatures had approved such a measure, and polls showed that three-quarters of the U.S. public supported a constitutional amendment. ${ }^{25}$ There were strong commonalities in attitude between the movement's leaders and scholars within the Public Choice school: disdain for the "theories of Lord Keynes"; frustration over the collusion of "selfish politicians and interest groups" in Washington; and, above all, the conviction that there was "only one way" to restore fiscal orderby constitutional reform. ${ }^{26}$

The balanced-budget movement fell short of attaining the thirtyfour state petitions that were necessary for Congress to call a constitutional convention. A second effort to amend the Constitution, beginning this time with votes in the House of Representatives and Senate, narrowly failed in 1982 . Too many politicians and professional economists expressed doubts about the wisdom of a constitutional restriction. This included some conservative experts like Alan Greenspan, who said that no "responsible economist" would support an amendment. ${ }^{27}$ By the early 1980s, Republican enthusiasm was tempered because of the effect of Reagan administration policies, which had produced larger deficits than in the 1970s. A balanced-budget requirement would have necessitated a major retreat from Reagan's commitments on tax relief and increased defense spending.

Still, the prolonged controversy brought attention and legitimacy to the idea of legal constraints on fiscal policy. In 1985, Congress passed the Gramm-Rudman-Hollings Balanced Budget Act, which established a

24. Buchanan, Balanced Budget, supra note 16, at 118.

25. See Adam Clymer, Carter Budget Gets Support in Survey: Public Backs Cuts in Spending as Key Way to Combat Inflation, N.Y. TIMES, Jan. 31, 1979, at A11.

26. Iwan Morgan, Unconventional Politics: The Campaign for a Balanced-Budget Amendment Constitutional Convention in the 1970s, 32 J. AM. STUD. 421, 421-424 (1998); Editorial, Burditt Urges Amendment Requiring Balanced Federal Budget, REGISTER-STAR (Rockford, Ill.), Oct. 13, 1974, at A3.

27. Tom Morganthau et al., Balance-the-Budget Boom, NewsweEK, Feb. 12, 1979, at 28. 
series of annual deficit targets, ending with a balanced budget in $1991 .{ }^{28}$ If the President and Congress failed to agree on a budget that came within ten billion dollars of the deficit target, the law required automatic spending reductions drawn equally from defense and select domestic programs. ${ }^{29}$ The theory was that the automatic reductions would be so universally unappealing that the President and Congress would be driven to meet the deficit target. Senator Phil Gramm, one of the statute's sponsors, described it as a "binding constraint" that was necessary to achieve long-term budget discipline; ${ }^{30}$ the Public Choice school has been credited with providing the "philosophical underpinning" for the law. ${ }^{31}$ President Reagan's Chief Budget Official, James C. Miller III-former student of James Buchanan-also described the law as "a kind of device ... that a Public Choice scholar would have advanced." 32 Buchanan himself lauded the statute as the best alternative to a constitutional balanced-budget requirement. ${ }^{33}$

The Gramm-Rudman-Hollings Act was amended in 1987 and then replaced by a new statute, the Budget Enforcement Act, in 1990.34 President George H.W. Bush promised that under the new law "budgetary discipline [would be] extended and strengthened." 35 It removed the binding deficit targets but established limits on some categories of federal spending for the next five years, with the threat of automatic cuts if the limits were not respected. It also established a new principle, known as pay-as-you-go (PAYGO), under which new legislative proposals for spending or tax reductions had to include offsetting provisions so that there was overall change in the deficit. The key elements of the Budget Enforcement Act were extended twice in the 1990 s and ultimately expired in $2002 .^{36}$

28. Balanced Budget and Emergency Control Act of 1985, Pub. L. No. 99-177, 99 Stat. 1037 (Gramm-Rudman-Hollings Act).

29. Sung Deuk Hahm et al., The Influence of the Gramm-Rudman-Hollings Act on Federal Budgetary Outcomes, 1986-1989, 11 J. PoL'Y ANALYSIS \& MGMT. 207, 208 (1992).

30. 100 Cong. Rec. 21,733 (1987) (statement of Sen. Gramm).

31. Jane Seaberry, GMU Teacher Wins Nobel in Economics, WASH. Post, Oct. 17, 1986.

32. See generally id.; Jane Seaberry, 'Public Choice' Finds Allies in Top Places; Economic Theory Flourishes at George Mason University, WASH. Post, Apr. 6, 1986.

33. See Jane Seaberry, Nobel Winner Sees Economics As Common Sense; Buchanan Says His Public Choice Helps Explain Political Actions, WASH. Post, Oct. 19, 1986, at C1.

34. Budget Enforcement Act of 1990, Pub. L. No. 101-508, 104 Stat. 1388-573.

35. George Bush, Statement on Signing the Omnibus Budget Reconciliation Act of 1990 (Nov. 5, 1990) (transcript available at The American Presidency Project at the University of California Santa Barbara), available at http//www.presidency.ucsb.edu/ws/pid=19000.

36. Bill Heniff JR. ET AL., CONG. RESEARCH SERV., 98-721, INTROduCtion to The FEDERAL BUDGeT PROCESS 5, 17-18 (2012). 


\section{ORDOLIBERALISM AND EUROPE'S ECONOMIC CONSTITUTION}

The European project on fiscal rules began in the period between the two world wars, and has its clearest roots in the work of a group of German lawyers and economists who became known as Ordoliberals. Ordoliberals were intellectuals who had been repulsed by the chaos of Germany's Weimar Republic during the 1920s. This chaos was economic and political. A poorly regulated market economy had spawned cartels, frauds, and violent clashes between capital and labor. The performance of government had been as equally disappointing as the economic chaos: undisciplined in monetary and fiscal policies, indulgent of powerful interests, and capricious in its application of the law. Ordoliberals drew two lessons from the Weimar years. The first lesson was a repudiation of the laissez-faire idea that markets could organize themselves. Rather, a strong state was essential to set rules that would prevent the market from devolving into a "vulgar brawl." 37 The second lesson was that the state itself had to be protected against assaults by the "hungry hordes of vested interests." ${ }^{8}$ Government needed to be "hedged in by . . . limitations and safeguards" so that it would not be "devoured by democracy." 39

We can see that Ordoliberals shared the Public Choice school's suspicion about the trustworthiness of democratic processes. There was another commonality: faith in the capability of law to prevent abuses, either in the sphere of politics or in the marketplace. "At the core of the ordoliberal program is the symbiotic character of the relationship between legal and economic process," observes David Gerber. "Law would provide basic principles of economic conduct, and government officials would have no discretion to intervene in the economy except for the purpose of enforcing those principles." 40 Ordoliberal thinking was shaped by the older German theory of the Rechsstaat, or the "law-based-

37. Werner Bonefeld, Freedom and the Strong State: On German Ordoliberalism, 17 NEW POL. ECON. 633, 637 (2012) (quoting Wilhelm Röpke, The Guiding Principles of the Liberal Programme, in STANDARD TEXTS ON THE SOCIAL MARKET ECONOMY 187, 188 (Horst Friedrich Wünsche ed., 1982)). For a brief overview of the origins of ordoliberalism, see, e.g., Mathias Siems \& Gerhard Schnyder, Ordoliberal Lessons for Economic Stability: Different Kinds of Regulation, Not More Regulation, 27 GoverNANCE: AN INT'L J. POL'Y, ADMIN., \& INSTS. 377 (2014) (clarifying the ordoliberal position on state intervention in market economies).

38. Wilhelm Roepke, The SOCIAL CRISIS OF OUR TIme 181 (Transaction Publishers 1992) (1942).

39. WILHELM RÖPKE, AGAINST THE TIDE 97 (Elizabeth Henderson trans., 1969).

40. David J. Gerber, Constitutionalizing the Economy: German Neo-Liberalism, Competition Law and the "New" Europe, 42 AM. J. COMP. L. 25, 46 (1994). 
state," which insists that state power must be "shaped and framed, bound and limited by the law ...."41

Advocates of Ordoliberalism played a critical role in the reconstruction of the West German state after the Second World War. The main architect of post-war economic policy, Ludwig Erhard, insisted that the state had a duty to resist all "special demands." Like the referee in a football game, its duty was simply "to lay down the order and the rules of the game." 42 The new government eliminated price controls, despite mass protests, and then pursued a strict anti-inflation monetary policy despite complaints about its dampening effect on growth. ${ }^{43}$ It also resisted demands for a Keynesian program of debtfinanced public expenditure. West Germany's 1949 Constitution actually forbade borrowing except in extraordinary circumstances. ${ }^{44}$ Rather than accumulating debt, the West German Government produced surpluses for investment in public infrastructure by "savagely overpricing and overtaxing the consumer." 45 It also fought a decade-long battle for a strict competition law, overcoming the opposition of German industry. 46

German Ordoliberalism had a large influence on the design of institutions for the emerging European common market. Perhaps this is not surprising. Ordoliberals believed that markets did not emerge or survive spontaneously, and that it was the duty of the statesperson to draft an "economic constitution"-that is, a formal legal-institutional framework - to govern the operation of a market economy. ${ }^{47}$ This is precisely what had to be done as European states negotiated the

41. Matthias Koetter, Rechsstaat und Rechtsstaatlichkeit in Germany, in UNDERSTANDINGS OF THE RULE OF LAW IN VARIOUS LEGAL ORDERS OF THE WORLD 1-2 (Gunnar Folke Schuppert ed., 2013).

42. Ludwig ERhard, Prosperity through Competition 102 (Edith Temple Roberts \& John B. Wood trans., 1958).

43. See Wolfgang F. Stolper \& Karl W. Roskamp, Planning a Free Economy: Germany 1945-1960, 135 J. INSTITUTIONAL \& THEORETICAL ECON. 374, 386 (1979).

44. See Prof. Dr. Markus Heintzen, Budgetary Balancing and Public Debt in German Constitutional Law at the Conference $l l$ Pareggio Di Bilancio 3 (May 24, 2013). See also Basic Law for the Federal Republic of Germany [Constitution] May 8, 1949 art. 115 (stating that credits may only be taken "in the case of extraordinary need").

45. Frederick G. Reuss, Fiscal Policy for Growth Without Inflation: The GERMAN EXPERIMENT 35 (1963). See also Stolper \& Roskamp, supra note 43, at 388 (discussing West Germany's use of force to stimulate savings and governmental surpluses).

46. See, e.g., Gerber, supra note 40, at 64-66 (explaining the history of the rise of the ordoliberals).

47. ViKTOR J. VANBerg, The Freiburg School: Walter Eucken AND Ordoliberalism, 6 (Walter Eucken Inst., Freiburg Discussion Papers on Constitutional Economics No. 04/11, 2004). 
treaties that laid the groundwork for economic integration. This groundwork quickly established the habit of referring to these treaties as the European Community's "economic constitution." David Gerber observes that the influence of Ordoliberal thinking was particularly evident in European Community competition policy, which emphasized clear rules against cartelization that were applied by experts who were insulated from political pressures. ${ }^{48}$

Ordoliberal principles were further advanced as the pace of European economic integration quickened during the 1980s. A 1986 treaty, the Single European Act, set the goal of establishing a unified European market by $1992 . .^{49}$ It was widely recognized that this would require currency reform so that trade was not hobbled by fluctuating exchange rates. The 1989 Delors Report outlined a plan for the European Community to adopt a single currency, but the report also acknowledged that this change would require difficult decisions about the institutional arrangements that would govern monetary and fiscal policy within the community after a single currency had been adopted. It was at this stage that the Ordoliberal approach again exercised its influence. The Delors Report followed German practice in recommending that a new European central bank should have strict independence from political authorities with the single goal of controlling inflation. The Report recommended "binding rules governing the size and financing of national budget deficits" to avoid tensions between monetary and fiscal policies..$^{50}$

The Delors recommendations were translated into law by the Maastricht Treaty of 1992. The Treaty created an autonomous European Central Bank with a mandate to maintain price stability. It also prohibited national governments from incurring budget deficits exceeding three percent of GDP, and total debt exceeding 60 percent of GDP, once the new single currency (the euro) was in use after 1999..$^{51} \mathrm{~A}$ procedure was established for punishing governments that broke these requirements. ${ }^{52}$ The Maastricht Treaty requirements spurred an

48. Gerber, supra note 40 , at $71-74$.

49. Single European Act, art. 13, Feb. 17, 1986, 1987 O.J. (L 169) 30.

50. Chairman of the Comm. for the Study of Econ. and Monetary Union, Rep. on Economic and Monetary Union in the European Community, 19 (Apr. 17, 1989) (Jacques Delors).

51. See Treaty on European Union, Protocol on Excessive Deficit Procedure (now TFEU protocol 12) (explains the provisions of article TEU art. 104 (now TFEU art. 126).

52. See Treaty on European Union art. 104 (as in effect 1993) (now TFEU art. 126) (instructing the Commission to file a report if a Member State does not meet the debt ratio requirements and requiring the Member State to take action in order to reduce the deficit); Treaty on European Union art. 105 (as in effect 1993) (now TFEU art. 127) (establishing that the European System of Central Banks shall supervise other financial 
interest in new fiscal rules at the national level, as countries prepared to meet the deficit and debt requirements as a condition for entry into the new Eurozone. ${ }^{53}$ The European Commission counted only thirteen fiscal rules operating in Member States in 1990, mainly affecting subnational levels of government. ${ }^{54} \mathrm{By} 2000$, over forty rules were in force, with more than half affecting central government or all levels of government combined. ${ }^{55}$

\section{BUdGet Institutionalists SET A GLOBAL NORM}

By the early 1990s many countries around the world-including the United States and European states, but also others-were struggling to deal with rising government debt, and experimenting with reforms to the process of budget making in the course of that struggle. These reforms included experiments with fiscal rules. This reality, and the active patronage of powerful institutions, spurred the rapid growth of a new inquiry within economics that came to be known as budget institutionalism.

Budget institutionalists actually worked within a sub-discipline of economics known as political economy, which aspired to use the "main tools of analysis" of economics to explain the evolution and operation of political institutions. ${ }^{56}$ One of the main assumptions was that institutions and policy outcomes were shaped by individuals who behaved rationally in the pursuit of their own interests. There was a commonality here with the older Public Choice scholarship. This was especially clear as budget institutionalists explained why spending appeared to have run out of control in many advanced democracies after the early 1970s. In a 2007 paper, researchers for the European Commission provided what was, by then, a standard account of the problem:

institutions); Treaty on European Union art. 108 (now TFEU art. 130) (prohibiting the governments of Member States from influencing the European Central Bank or of the national central banks in the performance of their tasks); Treaty on European Union, Protocol on Excessive Deficit Procedure (now TFEU protocol 12) (explaining the provisions of article TEU art. 104 (now TFEU art. 126)).

53. Joaquim Ayuso-i-Casals, et. al., Beyond the SGP. Features and Effects of EU National-Level Fiscal Rules, in EUROPEAN ECONOMY ECONOMIC PAPERS 191, 195 (Eur. Comm'n No. 275, 2007).

54. One country might have several rules.

55. Directorate-General for Econ. and Fin. Affairs for the European Comm'n, Public Finances in the EMU 2006, 152, No. 3 (2006).

56. Torsten Persson \& Guido Tabellini, Political Economics: Explaining ECONOMIC POLICY 2 (Karl Gunnar Persson ed., 2000). 
Post-war economic history provides evidence that fiscal authorities in industrialised countries may be prone to a 'deficit-bias', which shows up in large and persistent deficits and growing public debts .... There is growing agreement that the sources of the deficit bias is rooted in ... the system of incentives and rewards that shape the behaviour of fiscal authorities. Governments, being unsure to be re-elected, are inherently short-sighted and do not fully take into account the longer term implications of deficits. Groups in the society that benefit from a particular type of government spending do not fully internalise the costs of this expenditure, since the financing is generally spread among a wide set of contributors through taxation. This 'common pool problem' is at the source of overspending and the accumulation of deficits and debt over time..$^{57}$

Budget institutionalists also shared the Public Choice view that the "deficit bias" could be corrected if the budgeting process was guided by well-designed rules. In an influential 1992 paper funded by the European Commission, Jürgen von Hagen explained: "We start from the presumption that budgeting procedures, i.e., the rules according to which budgets are drafted by a government, amended and passed by parliament, and implemented by the government, have important consequences for the degree of fiscal stability attained."58 Von Hagen then asked whether budgeting procedures that gave more power to finance ministers, while limiting opportunities for parliamentary amendments, were more likely to produce balanced budgets. He found that such budgeting procedures did have this effect and concluded that "institutional reform of the budgeting process is a promising avenue to achieve a larger degree of fiscal discipline." 59 This led to an extensive body of research by several scholars that largely supported the view

57. Ayuso-i-Casals, et. al., supra note 53, at 192. For very similar explanations, see Gabriel Filc \& Carlos Scartascini, Budget Institutions and Fiscal Outcomes: Ten Years of Inquiry on Fiscal Matters at the Research Department 4 (Sept. 17, 2004) (Conference Paper Prepared for the Inter-American Bank's Research Department 10th Year Anniversary Conference), available

$a t$ http://events.iadb.org/calendar/eventDetail.aspx?lang=En\&id=2282 [hereinafter Budget Institutions]; INT'L MONETARY FUND, Promoting FisCal Discipline 3 (Manmohan S. Kumar \& Teresa Ter-Minassian eds., 2007); Xavier Debrun et al., Independent Fiscal Agencies, 23 J. of ECON. SuRveYs 44, 45 (2009).

58. Jürgen von Hagen, Budgeting Procedures \& Fiscal Performance in the European Community, COMM'N OF THE EUROPEAN COMMUNITIES ECON. PAPERS, no. 96, 1992, at 2.

59. Id. at 54 . 
that centralized budgeting procedures led to better control over taxing and spending. ${ }^{60}$

Budget institutionalists had an even stronger interest in the effect of fiscal rules on budget outcomes, and empirical work on this subject grew along with the number of rules adopted. Researchers developed more refined typologies of rules-discriminating, for example, by the legal basis of the rule, the level of government affected, and the variable (expenditure, deficit, debt) being controlled-and also more sophisticated methods of statistical analysis. ${ }^{61}$ Much of this research was supported by the European Commission and international organizations, most notably the International Monetary Fund. By the early 2000 s, many of these institutions were converging on the view that fiscal rules were an effective device for promoting budget discipline. According to a 2009 IMF report, "[e]mpirical studies suggest that national fiscal rules have generally been associated with improved fiscal performance."62 A 2014 IMF working paper concurred: "A growing literature has suggested that well-designed [fiscal rules] are generally associated with greater fiscal discipline."63 While a 2013 report from the European Commission added: "Well-designed rules-based frameworks are known to significantly enhance budget discipline."64

\section{The MESSY REALITY of FisCAL RULES}

The allure of fiscal rules was greatest when they were viewed from a distance: up close, experience with the operation of such rules was less satisfying. This was certainly the case in the United States, which began its experiments with statute-based fiscal rules in 1985, with the passage of the Gramm-Rudman-Hollings Act. Senator Phil Gramm had promised that the law would impose a "binding constraint" on federal fiscal policy.65 In practice, though, the years after 1985 provided a

60. See, e.g., Alberto Alesina, et al., Budget Institutions and Fiscal Performance in Latin America, 59 J. DEV. ECON. 253, 270 (1999); Budget Institutions, supra note 57, at 45; Gabriel Filc \& Carlos Scartascini, Budgetary Institutions, in THE STATE of STATE REFORM IN LATIN AMERICA, 157, 179 (Eduardo Lora ed., 2007).

61. See generally KOPITS \& SYMANSKY, supra note 2, for an important early work on this subject. For an illustration of how work had advanced in the following fifteen years, see generally Schaechter et al., supra note 7.

62. Int'l Monetary Fund, Fiscal Affairs Dep't Paper, Fiscal Rules: Anchoring Expectations for Sustainable Public Finance 15 (Dec. 18, 2009), available at https://www.imf.org/external/np/sec/pn/2009/pn09139.htm.

63. Jean-Louis Combes et al., Inflation Targeting and Fiscal Rules: Do Interactions and Sequencing Matter? 3 (Int'l. Monetary Fund, Working Paper No. 14/89, 2014).

64. Eur. Comm'n., Report on Public Finaces in the EMU 2013, 45, 4/2013 (2013).

65. Statement of Sen. Gramm, supra note 30. 
demonstration of how difficult it was to impose a binding constraint through statutes rather than constitutional provisions. Indeed, the 1985 law was immediately compromised because of a successful constitutional challenge to the mechanism that had been established to execute the "automatic" spending cuts that were supposed to provide an incentive for policymakers to reach a deal on deficit reduction.66 Congress amended the law to create an alternative mechanism in 1987.

This proved to be the least of the problems with the 1985 law. Critics soon complained that legislators were attempting to comply with its deficit targets through "reliance on overly optimistic economic and technical assumptions and transparent budget gimmickry."67 Even so, Congress could not actually meet its targets. In 1987, it amended the law to loosen the annual deficit reduction requirements, and extend the deadline for balancing the federal budget by two years, to 1993. The challenge of meeting the deficit targets continued, and was aggravated after the onset of a recession in the summer of 1990. In November 1990, Congress eliminated the binding deficit targets entirely. The new Budget Enforcement Act established caps on certain categories of expenditure instead of attempting to eliminate deficits entirely. But it also stated that "emergency appropriations" should not be counted against the spending caps, and it allowed those caps to be suspended entirely in times of war or low economic growth. ${ }^{68}$

In fact, the federal deficit did shrink and was eliminated entirely in 1998. Still, complaints about disrespect for the principles of the Budget Enforcement Act persisted. The spending caps were repeatedly modified in the 1990s, and there was a sharp increase in emergency appropriations, much of which "had little to do with actual emergencies."69 Irene Rubin has argued that respect for the law declined quickly when budget balance was regained. ${ }^{70}$ The Budget Enforcement Act expired in 2002, and the federal government returned to a pattern of chronic deficits, aggravated by new expenditures on homeland

66. Bowsher v. Synar, 478 U.S. 714, 736 (1986) (holding that the "automatic" spending cuts violated the Constitution because it gave Congress the power to execute the law).

67. Robert D. Reischauer, Taxes and Spending Under Gramm-Rudman-Hollings, 43 NAT'L. TAX. J. 223, 223 (1990).

68. Megan SuZanne Lynch, Statutory Budget ConTrols In EfFeCt Between 1985 AND 20029 (Cong. Research Serv. Rep. No. R41901, 2011), http:/fas.org/sgp/crs/misc/R41901.pdf.

69. Alan J. Auerbach, Federal Budget Rules: The U.S. Experience 5 (Nat'l Bureau of Econ. Research, Working Paper No. 14288, 2008).

70. See Irene Rubin, The Great Unraveling: Federal Budgeting, 1998-2006, 67 PUB. ADMin. REV. 608, 609 (2007). See also Barry Anderson \& Joseph J. Minarik, Design Choices for Fiscal Policy Rules, OCED J. on BUDGETING, Sept. 28, 2006, at 159 (discussing budget process rules in the context of the current pattern of rising fiscal deficits). 
security and wars in Iraq and Afghanistan after the terror attacks of September 11, 2001.

Experience with the debt and deficit rules established by the 1992 Maastricht Treaty was similarly unsatisfying. The 1989 Delors Report said that these requirements should operate as "binding constraints" on national fiscal policies, but advocates of fiscal discipline soon became concerned that national governments were not taking the treaty's requirements seriously. In 1995, the German Finance Minister, Theo Waigel, proposed that the European Union should adopt additional rules to enforce the Maastricht criteria. It was essential, Waigel argued, that national deficits should not exceed the Maastricht limit of 3 percent of GDP, "even in economically unfavorable periods."71 A 1997 agreement, the Stability and Growth Pact, followed Waigel's proposals closely. It established a mechanism for monitoring national fiscal policies and threatened substantial fines if governments violated the Maastricht rules.

The 1997 Pact was initially lauded as "one of the most remarkable pieces of policy coordination in world history." ${ }^{2}$ Its severe enforcement provisions seemed to work. Compliance with the Maastricht Treaty requirements was generally good in the period immediately before the adoption of the euro in 1999. Later, though, critics would ask whether this behavior had actually been motivated by the strong desire of national governments to assure their inclusion within the Eurozone when the new currency was launched, rather than by fear of punishment under the Pact. ${ }^{73}$ One country, Greece, also admitted in 2004 that it had manipulated its budget data so that it qualified for admission to the Eurozone in 2001.

The European economy weakened in 2001, as did the United States', and several major economies-including France and Germanyrepeatedly exceeded the Maastricht deficit limits. This was the first major test of the Stability and Growth Pact, and it was a debacle. The European Commission, following procedures laid out in the Pact, recommended enforcement actions against Germany and France. But the European Council, representing the national governments, refused to adopt the Commission's recommendations, and the European Court of

71. Proposal by Theo Waigel for a Stability Pact for Europe (November 1995), CVCE.EU 3 (Dec. 20, 2013), available at http://www.cvce.eu/content/publication/2005/7/4/50fc7cc30a4d-4762-9ee5-e312d32d41f1/publishable_en.pdf.

72. Marco Buti \& Gabriele Giudice, Maastricht's Fiscal Rules at Ten: An Assessment, 40 J COMmon MKT. STUD. 823, 830 (2002) (quoting Michael J. Artis, The Stability and Growth Pact: Fiscal Policy in the EMU, in INSTITUTIONAL, LEGAL AND ECONOMIC ASPECTS OF THE EMU 101, 155 (Fritz Breuss et al. eds., 2002)).

73. See id. at 827. 
Justice refused to overturn the Council's decision. ${ }^{74}$ The drafters of the Pact intended that their procedures should be "binding," one observer wrote in early 2005, "and yet they have been set aside when they clashed with economic and political reality."75 Two months later, European leaders agreed to modify the enforcement procedures so that they had more discretion to incur larger deficits during economic downturns or other exceptional circumstances.

European finance ministers attempted to renew their commitment to fiscal discipline in November 2007, affirming that compliance with the Stability Pact requirements was "a key priority." 76 But events intervened once again. The financial crisis of 2007-2008 caused government expenditures (including financial sector bailouts) to skyrocket, while revenues plummeted. By 2011, almost all of the Eurozone countries had fallen out of compliance with the Maastricht Treaty's deficit or debt restrictions. The response was to propose even more strengthening of oversight and enforcement mechanisms, first by issuing a set of new regulations adopted in 2011, then by passing a new treaty in 2012, and again by adopting further regulations in $2013 .{ }^{77} \mathrm{All}$ of these measures, however, make a show of toughening the constraints on national governments. For example, the 2012 treaty, known as the Fiscal Compact, requires that governments adopt national balancedbudget legislation, which must require "automatic" corrections when governments deviate from their budgetary targets. But national governments have still managed to preserve discretion. Constitutional amendments to mandate a balanced budget are not required, and the Compact recognizes the "prerogatives of national Parliaments" to decide whether the correction mechanisms should be adjusted in exceptional circumstances. ${ }^{78}$

As one can see, actual experience with fiscal rules in the United States and Eurozone countries has proven to be complicated. Such rules have tended to be pliable, rather than rigid, constraints on fiscal policy. This has been true in several other nations as well. ${ }^{79}$ This observation might seem to be at odds with the cheerful endorsements of fiscal rules that have been made by organizations, like the IMF, drawing on empirical research done by budget institutionalists. But these

74. See Case C-27/04, Comm'n v. Council, 2004 E.C.R. I-6679.

75. Charles Wyplosz, Fiscal Policy: Institutions Versus Rules, 191 NaT'L Inst. EcoN. REV. 64, 70 (2005).

76. Press Release, Council of European Union, 2822nd Council Meeting on Economic and Financial Affairs, at 10 (Oct. 9, 2007).

77. The measures are described in Int'l Monetary Fund, Budget Institutions in G-20 Countries: An Update, 2014 IMF POL. PAPERS 12.

78. TSCG, supra note 3, at art. 3.2.

79. See Roberts, supra note 8, at 59-61. 
endorsements must be treated cautiously. On a closer reading, the research itself is more nuanced.

Budget institutionalists have grappled with three major problems in their research. The first problem has to do with cause and effect. Do fiscal rules cause governments to pursue more stringent fiscal policies, or do governments that are already inclined toward austerity adopt fiscal rules as a sign of their policy commitments? Attempts to sort out this problem of causality through statistical analysis have had mixed results. ${ }^{80}$ The 2009 IMF report that endorsed the effectiveness of fiscal rules also conceded that "stronger political commitment to fiscal discipline ... could lead to both an improvement in performance and the adoption of rules." The report conceded that "there [was] no fully satisfactory methodology to deal with this issue" and that existing research that appeared to show a causal connection between fiscal rules and budget discipline "should be interpreted with some caution." 81

There are, in fact, many cases in which governments adopted fiscal rules after a major crisis had driven political leaders to pursue an austerity program. Sweden, for example, undertook a program of retrenchment following a financial crisis in the early 1990 s, but did not adopt a fiscal rule until 1997. The 2009 IMF report concedes that governments have often used fiscal rules "to lock-in earlier consolidation efforts rather than at the beginning of the fiscal adjustment." $82 \mathrm{~A}$ similar observation was made in an IMF study of four countries that adopted "fiscal responsibility laws," which sometimes contain numerical budgeting targets, with apparent success. The study observed that fiscal performance in those countries had "started to improve several years before the implementation of the law, suggesting that a fair amount of consensus for the need for fiscal prudence was already at play." 83

A second major problem with empirical studies on the effect of fiscal rules has to do with the fact that not all rules are alike. In particular, there is variation in the legal basis for a rule. Some rules are entrenched in constitutions whereas others are expressed only in governmental policy statements. Researchers, who have developed methods for measuring the extent to which a fiscal rule is embedded in

80. See, e.g., James M. Poterba \& Kim Rueben, State Fiscal Institutions and the U.S. Municipal Bond Market, in Fiscal InstituTions AND FisCAL PERFormance 181 (James M. Poterba et al. eds., 1999); Xavier Debrun et al., Tied to the Mast? National Fiscal Rules in the European Union, 23 ECON. POL'Y 298 (2008).

81. INT'L MONETARY FUND, FISCAL RULES-ANCHORING EXPECTATIONS FOR Sustainable Public Finances 19, 20 (2009).

82. Id. at 3 .

83. Ana Corbacho \& Gerd Schwartz, Fiscal Responsibility Laws, in PROMOTING FiscaL Discipline 58, 71 (Manmohan S. Kumar \& Teresa Ter-Minassian eds., 2007). 
"hard law," have recognized this variation. ${ }^{84}$ Their research has shown that the positive effect of fiscal rules occurs mainly when the rules are entrenched in hard law. This was the main lesson drawn from early studies of the balanced-budget requirements of U.S. state governments, which are typically contained in state constitutions. ${ }^{85}$ As Robert Inman explained in 1996, an effective balanced-budget rule "must be constitutionally, not statutorily, grounded; [and] there must be open enforcement by a politically independent agent capable of imposing significant penalties for deficit violations . . . ."86 Later research, drawing on the experience of other countries, reached a similar conclusion. Thus, the 2006 European Commission report that confirmed "a link between numerical rules [that is, fiscal rules that specified a numerical target] and budgetary outcomes" also cautioned that "the characteristics of fiscal rules matter .... Strong rules, enshrined in law or constitution and foreseeing automatic enforcement mechanisms, seem to have a larger influence." 87

The difficulty, as we have seen, is that nations are unlikely to bind themselves with "strong rules" or "hard law" with regard to taxing and spending by national rather than sub-national governments. In 2012, the International Monetary Fund determined that seventy-six countries had adopted 166 fiscal rules to control the fiscal policy of their national governments. ${ }^{88}$ Only five of these 166 rules were entrenched in national constitutions. Of the remaining rules, roughly one-third were based in statutes, while half were based in international treaties. ${ }^{89}$ In other words, national fiscal rules tend to be expressed in softer forms of law. ${ }^{90}$

We can understand why this is so: governments want to preserve their sovereignty over fiscal policy. But this means that general

84. See Jakob de Haan, Helge Berger \& David-Jan Jansen, Why Has the Stability and Growth Pact Failed? 7 INT'L Fin. 235, 237-38 (2004) (discussing the distinction between rules expressed in "hard" and "soft" law).

85. See Nat'l Conference of State Legislatures, NCSL Fiscal Brief: State BALANCED BUDGET REQUTREMENTS 3 (2010).

86. Robert P. Inman, Do Balanced Budget Rules Work? U.S. Experience and Possible Lessons for the EMU 4 (Nat'l Bureau of Econ. Research, Working Paper No. 5838, 1996).

87. Directorate-General for Econ. and Fin. Affairs for the European Comm'n, supra note 55 , at 15 .

88. One government could be bound by more than one rule: for example, there might be separate rules on deficits and debts, and overlapping rules expressed in different forms of law.

89. See Schaechter et al., supra note 7 , at 17 . The few remaining fiscal rules were expressed in political statements or agreements. Treaty obligations are mainly those agreed to by countries in the Eurozone.

90. For a discussion of European Union requirements as a form of soft law, see Ludger Schuknecht, EU Fiscal Rules: Issues and Lessons from Political Economy 14-16 (Eur. Cent. Bank, Working Paper No. 421, 2004). 
statements about the effectiveness of fiscal rules must be treated cautiously. It may well be the case that "well-designed" rules are effective in shaping fiscal outcomes. But this may not be a useful finding, at least with regard to the control of national-level fiscal policies, if practice shows that governments are reluctant to adopt welldesigned rules. The real question, then, is-are fiscal rules of the type that national governments are likely to adopt effective in shaping fiscal policy? The answer to this question is much more equivocal. Statutory rules can be amended or abandoned when they become inconvenient, and treaty obligations may be flouted, as experience in the European Union has shown.

A final difficulty that has been highlighted by research has to do with problems of drafting and compliance. Even if fiscal rules are embedded in "hard law," their effectiveness may be compromised if they are drafted so that governments preserve discretion over fiscal policy or if they can be easily evaded. And this is often the case. A 2012 survey found that one-fifth of countries excluded some types of revenue or expenditure from the targets contained in their fiscal rules, and that many rules also contained vaguely worded "escape clauses." 91 For example, India's 2003 fiscal responsibility law allows the central government to ignore targets "on grounds of national security or national calamity or such other exceptional grounds as the Central Government may specify." 92 The practice of evading fiscal rules by "creative financing devices" is also well established.93 "Rules can be circumvented in many ways," a 2010 IMF working paper concedes, "such as by creative accounting, including by generating overly optimistic forecasts of economic variables, and by strategically determining what categories of expenditure are kept off budget."94 Of course, judicial review might serve as a check against evasion, were it not for the general reluctance of courts to rule on politically sensitive questions. Some budget institutionalists have argued that another remedy might be to establish specialized and autonomous fiscal agencies to serve as "impartial enforcers" of fiscal rules. ${ }^{95}$ This is part of a general shift in the emphasis away from the power of fiscal rules by

91. See generally Schaechter et al. supra note 7 (discussing the reasons why governments prefer escape clauses and how they apply escape clauses).

92. The Fiscal Responsibility and Budget Management Act, No. 39 of 2003, INDIA CoDE $\S 4(2)(b)(2003)$.

93. Richard Briffault, Balancing acts: The Reality Behind State Balanced BUDGET REQUIREMENTS, 50 (1996).

94. Era Dabla-Norris et al., Budget Institutions and Fiscal Performance in Low-Income Countries 6, 7 (Int'l Monetary Fund, Working Paper No. WP/10/80, 2010).

95. Debrun et al., supra note 57 at 61 ; see also Schaechter et al., supra note 7 at 24 (discussing countries implementing independent fiscal agencies to enforce fiscal rules). 
themselves. The new prescription is for a "rules-based framework"-a more expansive concept that may also include more centralized budgeting processes as well as independent overseers of fiscal policy.

\section{THE POLITICS OF RETRENCHMENT: A REAPPRAISAL}

For some advocates of fiscal discipline experience with the actual operation of fiscal rules was very disappointing. These advocates shared the view that there was something wrong with democratic processes: these processes had a dangerous tendency toward ever-increasing expenditures and debt. Fiscal rules were supposed to counteract this tendency, but now it appeared that they did not work as efficiently as it had been hoped. Governments had refused to adopt strong rules or evaded those they already adopted. This implied that the expansionary tendencies of democratic governments would continue unabated. The "crisis of democracy," first observed in the early 1970s, seemed to persist forty years later. ${ }^{96}$

This was a story of failure and alarm, but it had a flaw. It underestimated the substantive progress that many countries had made on fiscal policy during the three decades in which they had experimented with fiscal rules. Admittedly, progress was uneven over time and between countries, but, on the whole, countries managed to bring their debt under control (See Figure 1). It was an exaggeration to say that democracies learned nothing during their three decades of experimentation with fiscal rules. Somehow they had responded to the challenge of fiscal stress.

There is, in fact, an alternative way of thinking about the experience of the last three decades, which yields a more charitable view about the performance of the advanced democracies, and also yields a more modest view about what law can contribute to the process of social change. This alternative view requires a basic shift in the approach that is taken to the problem of fiscal indiscipline. A common feature of much of the "fiscal rules" literature-whether of the Public Choice, Ordoliberal, or budget institutionalist varieties-is the tendency to regard expenditure and debt growth as an ineluctable and timeless feature of democratic systems. Granted, this literature is always motivated by concerns about indiscipline during a specific moment in history. But the problem of indiscipline is never specified as one that is

96. See John MicklethwaIt \& AdRIAN Wooldridge, The Fourth REvolution: The Global RACE TO REINVENT THE STATE 18-21 (2014) (discussing tax, spending, and efficiency issues plaguing modern democracies); NIALL FERGUSON, THE GREAT Degeneration: How Institutions DeCAY AND Economies Die 39-40 (Penguin Press ed. 2013) (2012) (discussing the debt burdens accumulated by Western democracies). 
peculiar to that historical moment. Rather, the problem is abstracted, and the diagnosis is made timeless: bad outcomes result from strategic behavior of self-interested actors operating within a certain set of rules. Sometimes, there is a twinge of recognition that there is something wrong with this approach. For example, as we saw earlier, James Buchanan admitted that U.S. democracy was not prone to indiscipline before the Second World War. But this recognition does not deter the practice of producing highly abstracted diagnoses of the causes of indiscipline.

It is not necessary to dismiss the abstracted explanation of fiscal indiscipline entirely, but a more powerful explanation would probably include factors that are peculiar to a specific place and time. To put it another way, it would recognize that pressure toward indiscipline is also context-contingent, and thus not necessarily an inevitable feature of the democratic process. In the United States, for example, we should account for several considerations that intensified the demand for expenditure in the post-war period.

One of the most important of these considerations is the predisposition of the generation that came to maturity in the $1960 \mathrm{~s}$ and early $1970 \mathrm{~s}$ - the baby boomers. They differed from preceding generations in several ways. First, they had grown up during a period of rapid economic expansion. Real GDP doubled between 1955 and 1974: the United States had not experienced that sort of sustained growth since before the First World War. Faith in the federal government was also extraordinarily strong-indeed, notably stronger than that of older Americans in that period. Throughout the 1960s, according to the American National Election Studies, more than two-thirds of baby boomers believed that they could trust the federal government to do the right thing most or all of the time. ${ }^{97}$ Again, this was an understandable response to recent history because the federal government had grappled with immense problems - the Depression, the Second World War, the Cold War-with apparent success.

Under such circumstances, it is probably not surprising that a host of new demands were made on federal authorities. And it is important to emphasize that these demands were not thrust on unwilling leaders. In the United States, and other advanced democracies, the establishment shared the public's faith in governmental capabilities and

97. See Trust the Federal Government 1958-2008, AM. NAT'L ELECTION STUD. tbl. 5.A.1.2 (Aug. 5, 2010), http://www.electionstudies.org/nesguide/2ndtable/t5a_1_2.htm [hereinafter Trust] (showing that from 1966 to 1968, of those surveyed at minimum 69\% of Americans born between 1927 and 1958 said they trusted the federal government all or most of the time). 
prospects for continued growth. The reality of the 1960 s, the journalist Theodore White wrote, was

liberal dominance, in Congress, in academia, in the press, on television, in the great foundations and 'think tanks.' Under Republican presidents, as under Democratic presidents, the liberal idea prevailed-that the duty of government was to conceive programs and fund them so that whatever was accepted as right and just, at home or abroad, would come to pass..$^{98}$

It was this faith that had motivated the launch of Lyndon Johnson's Great Society program in 1964. It included a large amount of confidence in the capability of federal authorities to manage the overall economy through the manipulation of taxing and spending, as Keynes had suggested. ${ }^{99}$ Even President Richard Nixon, a Republican, conceded that he was "a Keynesian in economics." 100

If the U.S. economy had sustained the same rate of GDP growth after 1974, there would be no anxiety about the level of federal debt today. ${ }^{101}$ However, the structure of the American economy changed profoundly in the following decades. Real GDP growth slumped to three percent in the period between 1975 and 2008. The pattern of international trade and finance also shifted. The United States began to import more goods and services than it exported, and became dependent on foreign investment to pay for that gap in trade. Slower growth meant that it was harder for the federal government to meet new demands for expenditure, while shifts in the patterns of finance meant that U.S. policymakers had to be more sensitive to the moods of overseas investors. The United States had not been in such a position since before the Civil War. ${ }^{102}$

98. Theodore H. White, America in Search of ItSelf: The MaKing of the PRESIDENT 1956-1980, at 24 (1982).

99. See John Kenneth Galbraith, The Public Sector is Still Starved, CHALLENGE, Jan.Feb. 1967, at 18, 21 (discussing Keynesian economics and the need for increased federal spending in the U.S. public sector).

100. Leonard Silk, Nixon's Program-'I Am Now a Keynesian', N.Y. TIMES, Jan. 10, 1971, at E1.

101. The GDP growth rate dropped by about one percent after 1974. This meant that GDP was about forty percent lower by 2008 . If GDP growth had not declined, the proportion of publicly held federal debt to GDP in 2008 would have been roughly what it was in 1974.

102. See ROBERTS, supra note 23 , at 5-11 (comparing the modern U.S. economy to the U.S. economy following the economic crises of $1836-1848$, particularly how the economy in both cases depended on foreign countries). 
The politics of the post-1974 era was preoccupied with the adjustment of public expectations to these new economic realities. This adjustment was a difficult process for at least three reasons. The first is that no one knew, at that time, whether the economy was undergoing a fundamental change, or merely suffering a temporary perturbation that could be managed using conventional techniques of economic control. Initially, and understandably, there was a strong inclination to believe that the problem was transient and manageable. In the United States, as in many other countries, much of the 1970s were spent with interventions that seemed likely to work based on previous experience. The results were miserable: economic stagnation and high inflation. In hindsight it might have been better to pursue different policies (including more rigorous expenditure and inflation control) earlier. Again, though, it took time for people to appreciate the scale of their economic troubles.

Another factor also complicated the process of adjustment. This factor was the need for a massive project of ideational change, both within the establishment and the public at large. Within the federal government, a generation of politicians and bureaucrats had refined a set of ideas about the role of government that predisposed them toward activism, particularly in the sphere of economic management. Some of these politicians and bureaucrats would gradually develop a new way of thinking about the federal role, while others would be removed or retired. In either case, the process of change was necessarily slow. Meanwhile a similar but much larger exercise had to occur within the voting population. This, too, required either the acquisition of new ways of thinking, or the slow displacement of one generation of voters by another. Finally, the process of change was complicated by the fact that policy choices made in the 1960s and 1970s were embedded in actual programs, and these programs were hard to change. The problem was not simply resistance from bureaucrats within federal programs. Millions of Americans were beneficiaries of these new initiatives, while millions more had made substantial educational and business investments that were predicated on the assumption that they would continue.

It was the task of the democratic process to make the adjustments necessary to accommodate new economic realities, and to do this in such a way that a sufficiently large proportion of the U.S. electorate accepted the adjustments. By the turn of the millennium, these adjustments had been largely accomplished. There was, for example, a significant shift in institutional arrangements within the federal government. One of the most noticeable changes was the rise of the Federal Reserve, whose role in preserving price stability was now regarded as critical by financial 
markets. In 1967, John Kenneth Galbraith said that the Federal Reserve ought to be regarded as "a minor instrumentality of the state. . . standing in importance between the Bureau of Printing and Engraving and the Interstate Commerce Commission." 103 Almost forty years later, the chairman of the Federal Reserve enjoyed "rock star status."104 Nevertheless, the story was not solely, or even primarily, about institutional change. There were important changes in elite and public opinion as well. Bill Clinton confirmed the transformation of establishment attitudes in 1996, when he declared that the "era of big government is over." 105 Meanwhile the public at large also became more skeptical about federal government programs. Of course, this included a large number of disillusioned baby boomers, but by 2008 it also included a larger number of adult Americans who had never held a favorable view of the federal government. 106 Accompanying these shifts in institutional arrangements and ideas was a shift in federal policy outcomes, including a much better record of inflation control, and a largely successful effort to contain the growth of federal expenditure (See Figure Two).

This process of adjustment had few features that would make it appealing to technocrats or financiers. It was slow, spanning decades. It was also prone to reversals. For example, budget discipline ebbed when economic growth rebounded in the late 1990s, and during the national security panic that followed the 9/11 attacks. Very often, progress could not be made until the country had reached the brink of crisis. ${ }^{107}$ The United States was not alone in this regard. Many other advanced democracies did not take the process of retrenchment seriously until they confronted a currency crisis (as New Zealand did in 1984, and

103. Galbraith, supra note 99 , at 21.

104. David Wessel, In Fed We Trust: Ben Bernanke's War on the Great Panic 50 (2009).

105. William J. Clinton, President, U.S., Address Before a Joint Session of Congress on the State of the Union (Jan. 23, 1996) (transcript available at http:www.presidency.ucsb.edu/ws/?pid=53091). In Britain, the former Labor Party cabinet minister Peter Mandelson echoed Nixon's famous comment about Keynes: "We are all Thatcherite now." David Charter, Mandelson Tells Labour: We're All Thatcherites, TIMES (London), June 10, 2002 (Home News).

106. The American National Election Studies have conducted biennial surveys of American voters since 1958. One question asks whether voters "trust the government in Washington to do the right thing." Trust, supra note 97. Only once (in 2002) did a slim majority of the cohort born in 1959-1974 say that they trusted the federal government most or all of the time. Id. The cohort born in 1975-1990 is similarly skeptical. Id.

107. See generally DAVID RUNCIMAN, THE CONFIDENCE TRAP: A HISTORY OF DEMOCRACY IN CRISIS FROM WORLD WAR I TO THE PRESENT (2013) (arguing that democracies grow complacent and only address major issues when faced with crises). 
Sweden did in 1992) or the risk of an imminent currency crisis (as Canada did in 1993).

The United States, as the dominant economic power, was not vulnerable to exactly this sort of shock. Nevertheless, it did suffer through repeated episodes in which policymakers seemed willing to go to the brink of financial disruption before agreeing on new fiscal policies. In 1985, the United States risked default when the Republican president and the Democrat-controlled House of Representatives could not agree on an adjustment to the statutory limit on federal borrowing: this episode unsettled financial markets but eventually produced the Gramm-Rudman-Hollings law. There was another standoff between a Republican president and a Democratic Congress in 1990, this time triggered by the risk of deep cuts required by the Gramm-RudmanHollings law. This led to a brief government shutdown, but also a new agreement on fiscal policy, contained in the Budget Enforcement Act. There was a third budget crisis in late 1995, this time between a Democratic president and a Republican Congress, which again involved a risk of default because of Congress' refusal to raise the debt limit, as well as a three week government shutdown. This crisis was followed by repeated small conflicts over the debt ceiling throughout the early 2000s, and two larger debt-ceiling crises in 2011 and 2013, which led to yet another shutdown but also new legislation to control longer-term spending. 108

What role had fiscal rules played in this decades-long process of adjustment? Clearly they played some sort of role. The GrammRudman-Hollings Act and the Budget Enforcement Act were compacts, or treaties: they gave expression to the settlement that was reached at a particular moment of time between rival factions on questions of taxing and spending. These laws also gave reassurance to voters and investors about the intentions of federal policymakers, affirming and bolstering the shift in public attitudes toward a more conservative fiscal policy. Finally, these laws made it somewhat harder-although certainly not impossible-for policymakers to shift away from a policy of retrenchment. It became more difficult to increase spending, partly

108. See D. ANDREw Austin \& Mindy R. Levit, Cong. ResearCh SERV., RL31967, ThE DEBT LIMIT: HISTORY AND RECENT INCREASES 3-14 (2010) (discussing the debt limit issues from 2002 to 2009); MINDY R. LEVIT ET AL., CONG. RESEARCH SERV., R41633, REACHING THE DEBT LIMIT: BACKGROUND AND POTENTIAL EFFECTS ON GOVERNMENT OPERATIONS 68 (2013) (discussing the debt limit issues of 2011 and 2013, and the Budget Control Act of 2011). See generally Clinton T. BRASS, Cong. RESEARCH SERV., RL34680, SHUTdown of the Federal Government: Causes, Processes, AND Effects (2013) (discussing the effects a shutdown has on various agencies of the federal government). 
because the law created new procedural hurdles, and because it obliged politicians to renege on high-profile commitments to budget discipline.

Would it be fair to go further and say that these fiscal rules had caused retrenchment at the federal level? This was the hypothesis advanced by budget institutionalists. But it is difficult to see how this could be the case. Fiscal rules embedded in statutes could not restrain politicians and voters who were not already agreed on the idea of discipline. When the power of rival factions in Washington shifted, or popular sentiment changed, then the law that had expressed the prevailing political settlement gave way. It follows from this that the more important determinant of fiscal policy was probably elite and public opinion about the role of the federal government and its fiscal policy and the relative power of rival camps in Washington. The shift toward discipline happened after a long war of ideas, evolving in response to experience over time, and because of shifts in power from one generation to the next.

\section{DEMOCRATIC FaILURE OR DEMOCRATIC SUCCESS?}

As we have seen, many advocates of fiscal rules overestimated their importance as constraints on national policymaking. These advocates tended to have a simplistic view of how politics worked and an excessive faith in the capability of institutional reforms to cause changes in the content of fiscal policy.

Nevertheless, advocates of fiscal rules were not alone in these misapprehensions. Some critics of fiscal rules shared these views about the nature of politics and the power of law. They differed from advocates of fiscal rules mainly in their appraisal of the anticipated effects of those rules. Advocates of fiscal rules liked the expected outcome, which was fiscal discipline. Critics disliked the constraint that was imposed on democratically elected politicians and voters. This was an argument that extended to other institutional reforms as well, such as laws to reinforce the autonomy of central banks, regulatory agencies, or bodies that were involved in the facilitation of trade and investment. On one side were people who argued that these reforms were essential to the smooth operation of a globalized market economy. On the other side were people who argued that these were pernicious constraints on the democratic process. ${ }^{109}$ However, advocates and critics alike shared the assumption that institutional innovations had some effect-that is, they

109. See, e.g., RoBERTs, supra note 11; Thomas Meaney \& Yascha Mounk, What Was Democracy?, ThE NATION, June 2, 2014, at 24. 
assumed that these institutional innovations actually constrained the normal operation of democratic politics.

Were the critics right? One objection was that fiscal rules were rarely forced on national governments. Democratically elected politicians choose to adopt them, and as a result, the reforms could be said to have democratic legitimacy. ${ }^{110} \mathrm{This}$, however, is probably not the right way to frame the objection. We can easily imagine a situation where a democratically elected legislature adopts a law that effectively destroys the democratic system. An extreme example is the Enabling Act passed by the Reichstag in 1933, which gave total power to the chancellor, Adolf Hitler. The fact that the Reichstag had a claim to democratic legitimacy hardly made the new regime defensible. ${ }^{111}$ The critical question is probably whether democratically elected politicians retain the power to reverse their reforms at some later point. The legitimacy of reforms is demonstrated by the virtue of the fact that voters and politicians have preserved the power to undo them, and choose not to exercise that power.

As a matter of experience regarding fiscal rules, we can see that national governments have been careful to preserve their capability to undo reforms. Particularly at the national level, politicians largely avoid rules that are expressed in forms (e.g., constitutional amendments) that make it harder to reverse course later. Governments also seek to preserve discretion through vague wording, and they often reverse themselves, either explicitly or implicitly. They amend or abandon legislation and ignore or evade legal requirements. "Binding constraints" and "automatic mechanisms" rarely prove to be binding or automatic in practice. Ultimately, sovereignty over fiscal policy is preserved. In this respect, the threat to democratic principles that is posed by fiscal rules would seem to be overstated.

We might go a step further. Not only was the autonomy of democratic institutions not seriously undermined by fiscal rules during the neoliberal era, but also, more positively, democratic systems demonstrated their capability to respond to the problems of rising expenditure and debt. In 1980, one of President Carter's chief economic advisers, Alfred Kahn, had lamented the "constant forces to increase expenditures ... to expand government programs," and wondered: "Can

110. See Richard Allen, The Logic of Discipline: Global Capitalism and the Architecture of Government, 24 GovERNANCE 739, 740 (2011) (book review) for an example of this argument.

111. In fact, there is room to doubt that this law was properly adopted: many legislators were unable to vote or were threatened with violence. 
a democracy discipline itself?"112 The answer might now appear to be: "Yes, it can." It may not do this as quickly or systematically as an authoritarian regime, and often it might need to be jolted by crisis. On the other hand, the result has a degree of legitimacy that cannot usually be produced by the action of an authoritarian regime. Some people may not like the results of retrenchment within a democracy, but most people accept that the decision to pursue that policy was properly made. ${ }^{113}$

There are three possible objections to this argument. The first objection is that retrenchment runs the risk of responding to an excessively abstract critique of the democratic process with an equally abstract defense. It may well be that the United States answered Kahn's question affirmatively over the last three decades: experience in other countries may differ. This is fair comment. It would be better to say that in a particular country, in a particular period, fiscal problems were eventually addressed-and so, in that country, the critique of democracy was rebutted.

A second objection is that we have overestimated the degree of legitimacy that attaches to the outcomes that have been generated by U.S. federal politics over the last three decades. Here, we are obliged to acknowledge that most U.S. citizens now express a very low level of trust in federal government, as well as a strong sense that the country is heading in the wrong direction overall. ${ }^{114}$ However, this evidence must be interpreted carefully. Trust may be low relative to levels of the 1950 s and 1960s, but we have no way of knowing whether the immediate postwar period was itself an anomaly. To some degree, the decline in trust may be precisely the outcome that is desired: that is, it may reflect a weakened propensity to make demands on the federal government. 115 What might be more important are behavioral measures of legitimacy, such as the extent of protest, disrespect for law, and withdrawal from forms of political participation. However, from this point of view there is still no strong evidence of an approaching crisis of

112. WHITE, supra note 98, at 149 (quoting Alfred Kahn, one of President Carter's chief economic advisers).

113. On the definition and measurement of state legitimacy, see BRUCE GILLEY, THE Right to RuLE: How States WIN AND Lose Legitimacy 3-16 (2009).

114. See Alasdair Roberts, The Government We Deserve, FoREIGNPOLICY.COM (May 21, 2012), http://www.foreignpolicy.com/articles/2012/2005/2021/the_government_we_deserve (arguing an era of neoliberal policies reduced the confidence U.S. citizens have in the federal government and the direction of the country).

115. It is noteworthy that there has been no similar shift in trust in state and local government over the last four decades. 
legitimacy. ${ }^{116}$ As to concern about the direction in which the country is heading, this can be affected more directly by other factors, such as economic restructuring or ill-considered wars.

A third objection has to do with developments after 2008. In this paper, I have avoided discussion about the global financial crisis' impact on deficits and debt. The crisis did cause a substantial deterioration in public finances, but it is difficult to argue that this had much to do with the sort of "democratic overload" that has preoccupied advocates of fiscal rules. It was a massive market crash, rather than rent-seeking by voters, politicians, and bureaucrats, that caused deficits after 2008. I have also avoided any discussion about what the United States and some other democracies have done (or rather, have failed to do) in anticipation of rising expenditures on old-age programs and healthcare in the next three decades. Some conservatives argue that the failure of policymakers to grapple with this problem is a sign of the dysfunction of American democracy. ${ }^{117}$ The scale of the problem is, indeed, daunting, ${ }^{118}$ and the desire for an immediate and comprehensive response is understandable. The experience of the last thirty years, however, has shown us that U.S. democracy does not work that way.

116. For a skeptical view of the West's "crisis of legitimacy," see GILLEY, supra note 113, at 19 .

117. See FERGUSON, supra note 96, at 41-42 (arguing that U.S. voters are passing off the cost of entitlement programs to future generations); MICKLETHWAIT \& WOOLDRIDGE, supra note 96, at 14-17 (Arguing that the United States and other Western democracies are faced with a crisis of debt partially due to pension obligations).

118. See generally U.S. Gov'T ACCOUNTABILITY OFFICE, LONG-TERM FEDERAL BUdGET SIMULATIONS: SPRING 2014 UPDATE (2014) (extrapolating what the fiscal budget and deficit could potentially look like in the future). 


\section{Figure 1: Central government debt as percent of GDP in OECD nations}

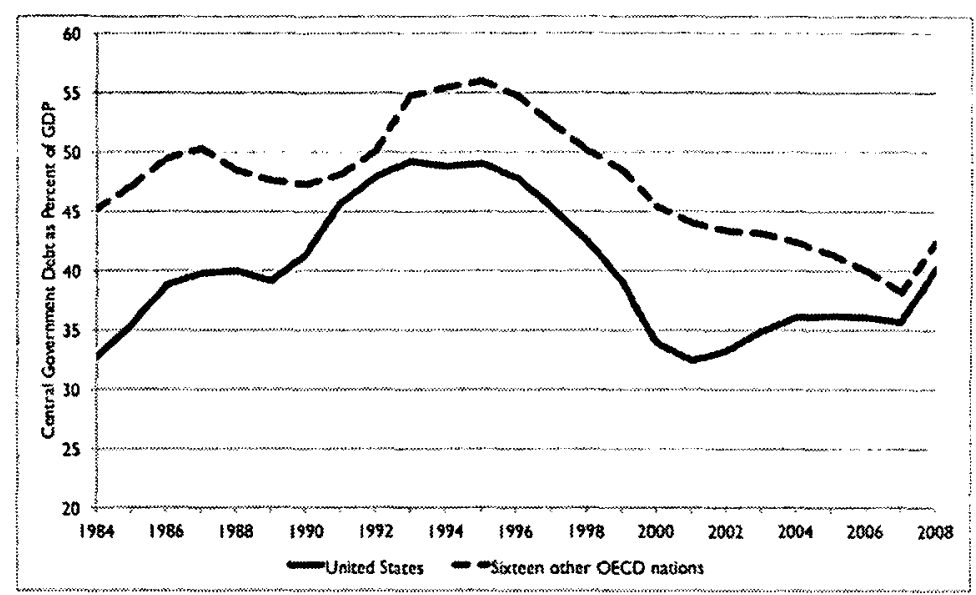

Source: Central Government Debt, OECD.Statextracts, available at http://stats.oecd.org/index.aspx?queryid=8089 (last updated Feb. 7, 2015). This chart shows publicly held central government debt as a percent of GDP. The average for sixteen other OECD countries includes all countries for which data was available for the whole period 1984 to 2008, except Japan, whose performance deviated substantially from that of all other OECD nations.

Figure 2: U.S. federal expenditure as percent of GDP

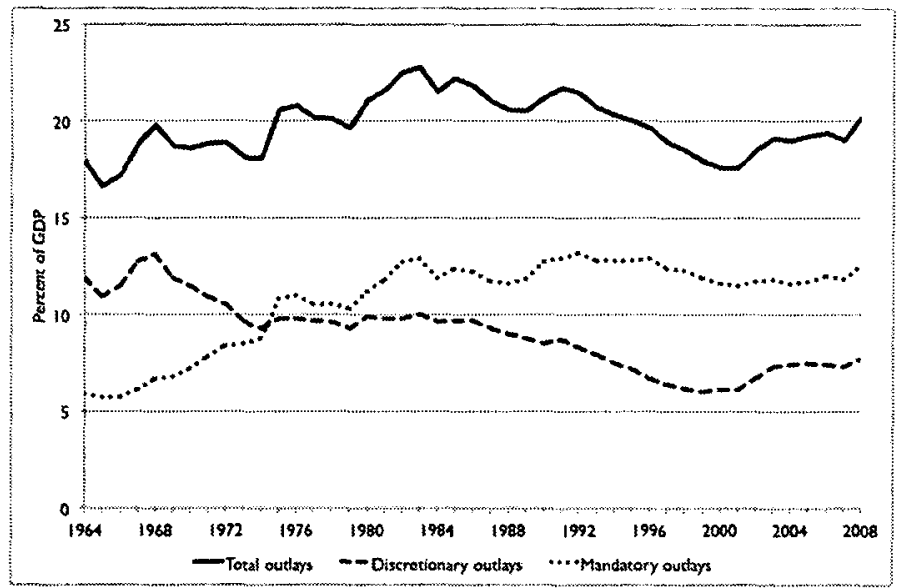

Source: Historical Tables, OfFICE MGMT. BUDGET, tbl. 8.4, available at http://www.whitehouse.gov/omb/budget/Historicals (last visited Feb. 7, 2015). 